\title{
Expansins: Cell Wall Remodeling Proteins with a Potential Function in Plant Defense \\ Synan AbuQamar
}

Department of Biology, College of Science, United Arab Emirates University, UAE

Cell wall $(\mathrm{CW})$ performs a number of important functions. This distinctive feature of plants determines cell structure, and plays major roles in intercellular communication and plant-microbe interactions, including defense responses against potential pathogens. Expansins are novel plant $\mathrm{CW}$ loosening proteins, are mainly involved in the $\mathrm{pH}$-dependent extension of plant CWs that is called acid growth $[1,2]$. These plant CW remodeling proteins have important roles in plant cell growth, fruit softening, abscission, and emergence of root hairs, pollen tube invasion of the stigma and style, meristem function, pathogenicity and developmental processes. Expansins are linked with cell growth and CW changes that are induced by a number of plant hormones.

In plants, two main families of expansin genes have been discovered: -expanins (EXPA) and $\beta$-expansins (EXPB). Other expansin-like genes, such as expansin-like $A(E X L A)$ and expansin-like related (EXLB), have also been identified in plants. For example, in the genome of Arabidopsis thaliana and rice (Oryza sativa), 26 and 33 genes of EXPA, 6 and 18 of EXPB, 3 and 4 of EXLA, in addition to one EXLB gene, respectively, were identified. Thus the function has not been well-studied [2-5]. Recently, the Arabidopsis expansin-like A2 (EXLA2) gene has been reported to link plant development and defense [6].

Expansin proteins are relatively conserved. A typical mature protein has a molecular weight of 25 -30 kilo Dalton, which corresponds to 250-300 amino acids. Expansin proteins are composed of two conserved domains: Domain I (120-135 aa), a glycoside hydrolase-like family 45 (GH45-like) at the amino (N) terminal; and Domain II (90$120 \mathrm{aa})$, a group- 2 grass pollen allergen at the carboxyl (C) terminal [5]. An expansin signal peptide (SP) of $20-30$ aa is also found at the $\mathrm{N}$-terminal end, suggesting that this SP may direct the polypeptide into the endoplasmic reticulum (ER)/Golgi secretory pathway $[2,7]$. A number of conserved cysteines are present in domain I, yet no hydrolytic activity has been detected. In addition, all expansinlike proteins have one to three NXT/S motifs, which may be N-linked glycosylation sites [8]. Expansin-like proteins, unlike other expansins, lack the HFD motif at the conserved motif of the GH45 active site, and have a unique conserved motif (CDRC) at the N-terminus of domain I, and an extension of sequence in domain II $[5,9]$. This deletion in domain I and the insertion in domain II of expansin-like proteins may lead to a different mechanism of action from that of other expansins [6].

In general, expansins are $\mathrm{CW}$ remodeling agents with endogenous functions in CW extensibility. Expansins are expressed in the early stages of symbiosis of the arbuscular mycorrhizal fungus Glomus intraradices on tomato (Solanum lycopersicum) and in developing nitrogen-fixing nodules in legumes [10,11]. Expansins are also expressed under drought conditions. During dehydration, the resurrection plant (Craterostigma plantagineum) expresses -expansin in leaves [12]. In response to cold stress, three EXLA genes are induced in Arabidopsis [13]. A recent study has shown that EXLA2 is also involved in the pathogenesis of necrotrophic pathogens and in the tolerance to abiotic stresses [5]. So far, no enzymatic activity has been found for expansins.

Expansins are well-known in loosening CWs via a nonenzymatic mechanism by inducing the slippage of cellulose micro fibrils in the plant CW [2]. The recent study of the role of EXLA2 in plant defense has uncovered a different mechanism of action from that of other expansins [6]. Mutations in EXLA2 enhance not only resistance to necrotrophic fungi, but also tolerance to phytoprostane $\mathrm{A}_{1}$. AbuQamar and his group demonstrate that down-regulation of EXLA2 alters the expression of cyclopentenone-regulated genes in response to $B$. cinerea. There appears to be a common regulation between electrophilic oxylipins and $B$. cinerea that is associated with EXLA2. On the other hand, EXLA2 is induced by salinity and cold, and by abscisic acid (ABA) treatment. In addition, the exla2 mutant showed hypersensitivity to increased salt and cold that is mediated by ABA. The work of EXLA2 presents convincing data that expansins contribute significantly to plant response to stress and impact signaling pathways that regulate gene expression. Future investigations into the mechanism of action of expansins open a new line of research in the field of plant responses to biotic and abiotic stresses at the biochemical, molecular and physiological levels.

\section{References}

1. McQueen-Mason S1, Durachko DM, Cosgrove DJ (1992) Two endogenous proteins that induce cell wall extension in plants. Plant Cell 4: 1425-1433.

2. Cosgrove DJ (2000) Loosening of plant cell walls by expansins. Nature 407 321-326.

3. Kim ES, Lee HJ, Bang WG, Choi IG, Kim KH (2009) Functional characterization of a bacterial expansin from Bacillus subtilis for enhanced enzymatic hydrolysis of cellulose. Biotechnol Bioeng 102: 1342-1353.

4. Kende H, Bradford K, Brummell D, Cho HT, Cosgrove D, et al. (2004) Nomenclature for members of the expansin superfamily of genes and proteins. Plant Mol Biol 55: 311-314.

5. Sampedro J, Cosgrove DJ (2005) The expansin superfamily. Genome Biol 6 242.

6. Abuqamar S, Ajeb S, Sham A, Enan MR, Iratni R (2013) A mutation in the expansin-like A2 gene enhances resistance to necrotrophic fungi and hypersensitivity to abiotic stress in Arabidopsis thaliana. Mol Plant Pathol 14: 813-827.

7. Boutté Y, Vernhettes S, Satiat-Jeunemaitre B (2007) Involvement of the cytoskeleton in the secretory pathway and plasma membrane organisation of higher plant cells. Cell Biol Int 31: 649-654.

8. Lee $\mathrm{Y}$, Kende $\mathrm{H}$ (2002) Expression of alpha-expansin and expansin-like genes in deepwater rice. Plant Physiol 130: 1396-1405.

9. Lee $Y$, Choi D, Kende $H$ (2001) Expansins: ever-expanding numbers and functions. Curr Opin Plant Biol 4: 527-532.

*Corresponding author: Synan AbuQamar, Department of Biology, College of Science, United Arab Emirates University, UAE, Tel: +971 3 713-6733; E-mail: sabuqamar@uaeu.ac.ae

Received January 06, 2014; Accepted January 07, 2014; Published January 15 2014

Citation: AbuQamar S (2014) Expansins: Cell Wall Remodeling Proteins with a Potential Function in Plant Defense. J Plant Biochem Physiol 1: e118. doi:10.4172/2329-9029.1000e118

Copyright: @ 2014 AbuQamar S. This is an open-access article distributed under the terms of the Creative Commons Attribution License, which permits unrestricted use, distribution, and reproduction in any medium, provided the original author and source are credited. 
Citation: AbuQamar S (2014) Expansins: Cell Wall Remodeling Proteins with a Potential Function in Plant Defense. J Plant Biochem Physiol 1: e118. doi:10.4172/2329-9029.1000e118

10. Dermatsev V, Weingarten-Baror C, Resnick N, Gadkar V, Wininger S, et al. (2010) Microarray analysis and functional tests suggest the involvement of expansins in the early stages of symbiosis of the arbuscular mycorrhizal fungus Glomus intraradices on tomato (Solanum lycopersicum). Mol Plant Pathol 11: 121-135.

11. Giordano W, Hirsch AM (2004) The expression of MaEXP1, a Melilotus alba expansin gene, is upregulated during the sweetclover-Sinorhizobium meliloti interaction. Mol Plant Microbe Interact 17: 613-622.
12. Jones L, McQueen-Mason S (2004) A role for expansins in dehydration and rehydration of the resurrection plant Craterostigma plantagineum. FEBS Lett 559: 61-65.

13. Lee BH, Henderson DA, Zhu JK (2005) The Arabidopsis cold-responsive transcriptome and its regulation by ICE1. Plant Cell 17: 3155-3175.
Citation: AbuQamar S (2014) Expansins: Cell Wall Remodeling Proteins with a Potential Function in Plant Defense. J Plant Biochem Physiol 1: e118. doi:10.4172/2329-9029.1000e 118
Submit your next manuscript and get advantages of OMICS Group submissions

Unique features:

- User friendly/feasible website-translation of your paper to 50 world's leading languages

- Audio Version of published paper

Digital articles to share and explore

Special features:

300 Open Access Journals

25,000 editorial team

21 days rapid review process

Quality and quick editorial, review and publication processing

Indexing at PubMed (partial), Scopus, EBSCO, Index Copernicus and Google Scholar etc

- Sharing Option: Social Networking Enabled

- Authors, Reviewers and Editors rewarded with online Scientific Credits

- Better discount for your subsequent articles

Submit your manuscript at: http://www.omicsonline.org/submission/ 